\title{
Microbiological, biochemical and compositional changes during ripening of São Jorge - a raw milk cheese from the Azores (Portugal) is
}

\author{
J. Marcelino Kongo a,b, Ana M. Gomes ${ }^{a}$, F. Xavier Malcata ${ }^{\mathrm{a}, *}$, P.L.H. McSweeney ${ }^{\mathrm{c}}$ \\ ${ }^{a}$ Escola Superior de Biotecnologia, Universidade Católica Portuguesa, Rua Dr. António Bernardino de Almeida, P-4200-072 Porto, Portugal \\ ${ }^{\mathrm{b}}$ Centro de Investigação de Recursos Naturais, Departamento de Biologia da Universidade dos Açores, Rua Mãe de Deus, P-9500-801 Ponta Delgada, Portugal \\ ${ }^{\mathrm{c}}$ Department of Food and Nutritional Sciences, University College, Cork, Ireland
}

\author{
Keywords: \\ Cheese \\ São Jorge \\ Biochemistry \\ Evolution \\ Proteolysis \\ Aroma \\ Microbiology \\ Composition
}

\section{A B S T R A C T}

The microbial, compositional and biochemical profiles of São Jorge cheese (PDO) obtained from three distinct cheese plants, throughout the ripening period were determined. Fully ripened cheeses (i.e. by 130 days) contained a total of $3.1 \times 10^{7} \mathrm{CFU} \mathrm{g}^{-1}$ mesophilic bacteria, and a decrease in moisture content, concomitantly with an increase in salt content, was observed throughout the same time frame. The $\mathrm{pH}$ decreased until 30 days of ripening; thereafter, a slight increase was reported, up to 5.6 by the end of ripening. Urea-PAGE results showed extensive primary proteolysis, of both $\beta$-casein and $\alpha_{s 1}$-casein degraded at essentially similar rates; plasmin and chymosin accordingly appear to be active in the cheese curd. RP-HPLC profiles of water-soluble fractions showed minor differences between 1 and 130 day old cheeses, whereas equivalent profiles of $7 \%(\mathrm{v} / \mathrm{v})$ ethanol-soluble fractions contained several peaks, indicative of a heterogeneous mixture of products of proteolysis, that evolved with time.

\section{Introduction}

Cheese ripening is a slow process, involving a concerted series of microbiological, biochemical, and chemical reactions, such as glycolysis, lipolysis and proteolysis (Singh, Drake, \& Caldwallader, 2003).

The unique flavours of the individual cheeses develop during ripening, and are highly dependent on the type of starter and in many cases of secondary inocula added to, or gaining access to the cheese milk or curd (Fox, 1993; Rehman et al., 2000). On the other hand, the physicochemical parameters - $\mathrm{pH}$, water activity and salt concentration - necessary to direct the biochemical reactions are set during manufacturing of cheese curd. Deviation from these three parameters, may lead to cheeses with inconsistent texture and/or flavour. Thus, curds for different cheese varieties are recognizably different at the end of manufacture, mainly as a result of compositional and textural differences arising from differences in milk composition and processing factors (Singh et al., 2003).

Proteolysis is the major - and certainly the most complex of biochemical events that take place during ripening of most cheese varieties; it affects, to important extents, both development of texture - via cleavage of caseins - and of flavour - via formation of precursors, that later undergo conversion to volatile flavour compounds (Fox \& McSweeney, 1996). Active proteolytic agents include enzymes indigenous to milk (plasmin) and rennet (pepsin and chymosin), or released by starter, non-starter and adjunct starter microorganisms (Hayaloglu, Guven, Fox, Hannon, \& McSweeney, 2004; Sousa, Ardo, \& McSweeney, 2001). The activities of the aforementioned enzymes - which are affected by $\mathrm{pH}$ of the curd, as well as salt-in-moisture content of the cheese (both of which vary with ripening time) are responsible for depletion of $\alpha_{\mathrm{s} 1}$-casein and $\beta$-casein (Gaiaschi, Beretta, Poiesi, \& Conti, 2001). At different phases of cheese manufacture (premanufacture, coagulation and ripening), different proteolytic enzymes may predominate, leading to characteristic casein residues (Fox \& McSweeney, 1996).

Protein in cheese is broken down from casein to low molecular weight peptides and amino acids by various kinds of proteolytic enzymes. During coagulation, the initial step of casein hydrolysis is performed by chymosin (milk coagulant) and proteinases from starter lactic acid bacteria, starter moulds and other microorganisms. The further degradation of high molecular weight peptides produced at the initial step is catalysed to low molecular weight peptides by endopeptidases from lactic acid bacteria. Proteolysis during cheese ripening has an important role in forming the texture, body and flavour in all matured cheese. Subsequently, the

\footnotetext{
is This manuscript has been submitted for publication in Food Chemistry. It is not to be reproduced or cited without the written permission of the authors.

* Corresponding author. Tel.: +351 296683847.
} 
low molecular weight peptides are degraded to amino acids by exopeptidases from lactic acid bacteria.

The primary proteolysis may be effectively assessed by urea polyacrylamide gel electrophoresis (urea-PAGE), whereas subsequent formation of peptides (termed secondary proteolysis), which is brought about by peptidases of microbial origin, may be ascertained by reverse phase-high performance liquid chromatography (RP-HPLC); the latter technique also permits isolation and identification of a wide range of individual peptides.

Several studies (de Llano, Polo, \& Ramos, 1995; Fox, 1993; Marcos, Esteban, León, \& Fernandez-Salguero, 1979) have shown differences in the protein profiles produced, following primary proteolysis, in several cheese varieties, using urea-PAGE of water-insoluble and RP-HPLC of water-soluble fractions. In many cheese varieties, $\alpha_{\mathrm{s} 1}$-casein is degraded more extensively than is $\beta$-casein in a given time frame, and concomitantly generates different concentrations of primary degradation products, which have thus been suggested as a basis for classification of distinct varieties of cheese (Farkye \& Fox, 1991; Fox, 1993). Application of this approach has been used to discriminate between Comté cheeses, which were produced at different manufacturing plants, using chemical, microbiological and sensory features (Grappin, Beauvier, Bouton, \& Pochet, 1999).

São Jorge is a semi-hard Portuguese cheese, manufactured from fresh raw cows' milk acidified by a whey starter culture from the previous batch. It is produced, in small-scale dairies in the island of São Jorge (Azores) - and was granted a Protected Denomination of Origin (PDO) status in 1984. This cheese accounts for ca. $51 \%$ of the total production of traditional cheeses in Portugal, and has recently attained an important market share in the USA and Canada. The cheese making process involves filtration of whole raw milk through a fine cloth, followed by heating to $30-31^{\circ} \mathrm{C}$ in open steel vats. A natural whey culture, i.e. an aliquot of whey released on the previous day, is then added as starter, and calf rennet is used as coagulant. Upon coagulation for ca. $1 \mathrm{~h}$ at ca. $30^{\circ} \mathrm{C}$, the coagulum is cut, and the resulting curd is heated to $35-36{ }^{\circ} \mathrm{C}$; upon whey drainage, dry salting and hand milling, the curds are transferred to perforated steel moulds, which have previously been lined with a cloth. The subsequent pressing stage extends for $48 \mathrm{~h}$, after which cheeses are ripened for a minimum of 3-4 months. By the end of ripening (typically 4-6 months), São Jorge cheese (which is normally $8-15 \mathrm{~kg}$ in weight and cylindrical in shape) develops a unique spicy flavour, as well as irregular eyes in its bulk. Previous work (Kongo, Ho, Malcata, \& Wiedmann, 2006), has addressed the microbiological safety issues in São Jorge PDO cheese.

As far as our knowledge goes, proteolysis in São Jorge cheese has not yet been the subject of any consistent scientific study. Thus the present study was undertaken in order to make clear the proteolytic process in São Jorge cheese, via generating analytical data that can characterize the biochemical events that occur during ripening, allowing for future interventions for eventual improvement of the organoleptic quality of São Jorge cheese, and for potential identification of unique traits that might be candidates as quality markers.

\section{Materials and methods}

\section{Cheese sampling and preparation}

Three cheeses, manufactured according to the standard cheese making procedures legally set forth for São Jorge DOP, were obtained from three dairy farms. The cheeses were aseptically sampled at 1, 15, 30, 60, 90 and 130 days of ripening, using a PK $2008 \mathrm{~N}^{\circ} 3$ (KB, Switzerland) cheese sampler, for later submission to microbiological, chemical and proteolysis analysis. The outer layer (ca. 1-2 cm in depth) in each sample was removed and discarded, and a cylindrical sample (ca. $15-18 \mathrm{~cm}$ in depth) was aseptically prepared for analyses.

\section{Microbiological analyses}

For this type of analyses, $25 \mathrm{ml}$ of milk were diluted in a peptone saline solution; alternatively, $25 \mathrm{~g}$ of cheese, at 1, 30, 6090 and 130 days of maturation, were first dispersed in $2 \%(\mathrm{w} / \mathrm{v}$ ) aqueous sodium citrate and then diluted as previously indicated for milk. All samples were subsequently assessed for total viable counts of different microbial groups, via plating on the following media (all from Oxoid Basingstoke, Hampshire, UK): total mesophilic bacteria - plate count agar, PCA, incubated at $30^{\circ} \mathrm{C}$ for $48 \mathrm{~h}$; enterococci - kanamycin, aesculin azide, KAA, agar, incubated at $37^{\circ} \mathrm{C}$ for $48 \mathrm{~h}$; presumptive lactic acid bacteria - Rogosa agar and M17 agar, both incubated under microaerophilic conditions, at $30^{\circ} \mathrm{C}$ for $72 \mathrm{~h}$; enterobacteria - violet red bile glucose agar, VRBGA, incubated at $37^{\circ} \mathrm{C}$ for $24 \mathrm{~h}$; and yeasts and moulds - oxytetracycline gentamicin glucose yeast extract agar, OGYEA, incubated at $22{ }^{\circ} \mathrm{C}$ for $5 \mathrm{~d}$. One-way analysis of variance (ANOVA) was performed on the total counts in milk and cheeses from all dairies considered, using the software Origin v. 2.8 (MicroCal Software, Northampton MA, USA).

\section{Chemical analyses}

Cheese samples were assayed for: moisture, by the oven-drying method at $102{ }^{\circ} \mathrm{C}$ (IDF, 1986), salt, by titration with $\mathrm{AgNO}_{3}$ (James, 1999), fat, by Gerber method (James, 1999), total protein, by Kjeldhal method (IDF, 1993), and $\mathrm{pH}$, by direct insertion of a $\mathrm{pH}$ meter probe.

\section{Proteolysis analysis}

\section{Electrophoresis}

Water-soluble extracts of cheese were prepared according to Kuchroo and Fox (1982); pH was adjusted to 4.6 with $0.1 \mathrm{~N} \mathrm{HCl}$. The nitrogen content of the fractions was determined by the macro-Kjeldhal method (IDF, 1993), with results expressed as percentage of total cheese nitrogen. Urea-polyacrylamide gel electrophoresis (urea-PAGE) was performed on cheese crude extracts, using a Protean II vertical slab gel unit (Bio-Rad Laboratories, Watford, UK) and the stacking gel system method modified by Shalabi and Fox (1987). The gels were stained directly according to Blakesley and Boezi (1997). Upon destaining, gel slabs were digitalized with a scanner (Scanjet 6300 C, Hewllet Packard, USA), and resulting electrophoretograms were used to quantify bands using densitometric software (Image Master TotalLab 1D Gel analysis v. 1.11, Amersham Pharmacia Biotech, Uppsala, Sweden). Similar bands were recognized visually, and matched in the urea-PAGE gels, and peaks and areas of corresponding bands were measured densitometrically. Intact caseins and peptides released therefrom were quantitatively determined by integration of peak volumes, again using the densitometer.

\section{Liquid chromatography}

The 70\% ethanol-extract, of the previously obtained water-soluble extract, was prepared by adding absolute ethanol to an aliquot of the water-soluble extract, up to a final ethanol concentration of $700 \mathrm{ml} \mathrm{l}^{-1}$. The mixture was held for $30 \mathrm{~min}$ at $20^{\circ} \mathrm{C}$, and then centrifuged at $3000 \mathrm{~g}$ for $30 \mathrm{~min}$. The supernatant was filtered though Whatman $\mathrm{N}^{\circ} 1$ filter paper, and the ethanol removed from the filtrate using a rotary evaporator (Model RE100, Bibby Sterlin, Stone, UK) at $30^{\circ} \mathrm{C}$ under vacuum. The ethanol-soluble and -insoluble extracts were dispersed in water, and duly lyophilized. The peptide 
profile of the ethanol-soluble fraction was determined by reversephase, high performance liquid chromatography (RP-HPLC), using a 626 solvent delivery system, coupled with a 600 controller and a 717 plus auto-sampler (Waters, Milford MA, USA). Nuclosil C8 $(5 \mu \mathrm{m}$ particle, $300 \AA$ pore size $)$ guard $(4.6 \times 10 \mathrm{~mm})$ and analytical $(4.6 \times 250 \mathrm{~mm})$ columns (Macherey-Nagel $\mathrm{GmbH}$, Duren, Germany) were used. Eluates were monitored at $214 \mathrm{~nm}$, using a 9050 variable wavelength UV-vis Detector (Varian, Walnut Creek CA, USA) interfaced with an IBM compatible PC running on Millenium software (Waters). The elution solvents used were: solvent A, $1 \mathrm{ml} \mathrm{l}^{-1}$ of trifluoroacetic acid (TFA, sequential grade, Sigma, St Louis MO, USA) in deionised, HPLC-grade water (Milli-Q system, Waters); and solvent B, $1 \mathrm{ml} \mathrm{l}^{-1}$ of TFA in acetonitrile (HPLC grade, Labscan, Dublin, Ireland). Samples ( $4 \mathrm{mg} \mathrm{ml}^{-1}$ of each cheese) were dissolved in solvent A, and filtered through $0.45 \mu \mathrm{m}$ cellulose acetate filters (Sartorius $\mathrm{GmbH}$, Gottingen, Germany); $40 \mu$ of filtrate were then applied to the column, and eluted using the gradient described by Rehman, Feeney, McSweeney, and Fox (1998), at a flow rate of $0.75 \mathrm{ml} \mathrm{min}^{-1}$.
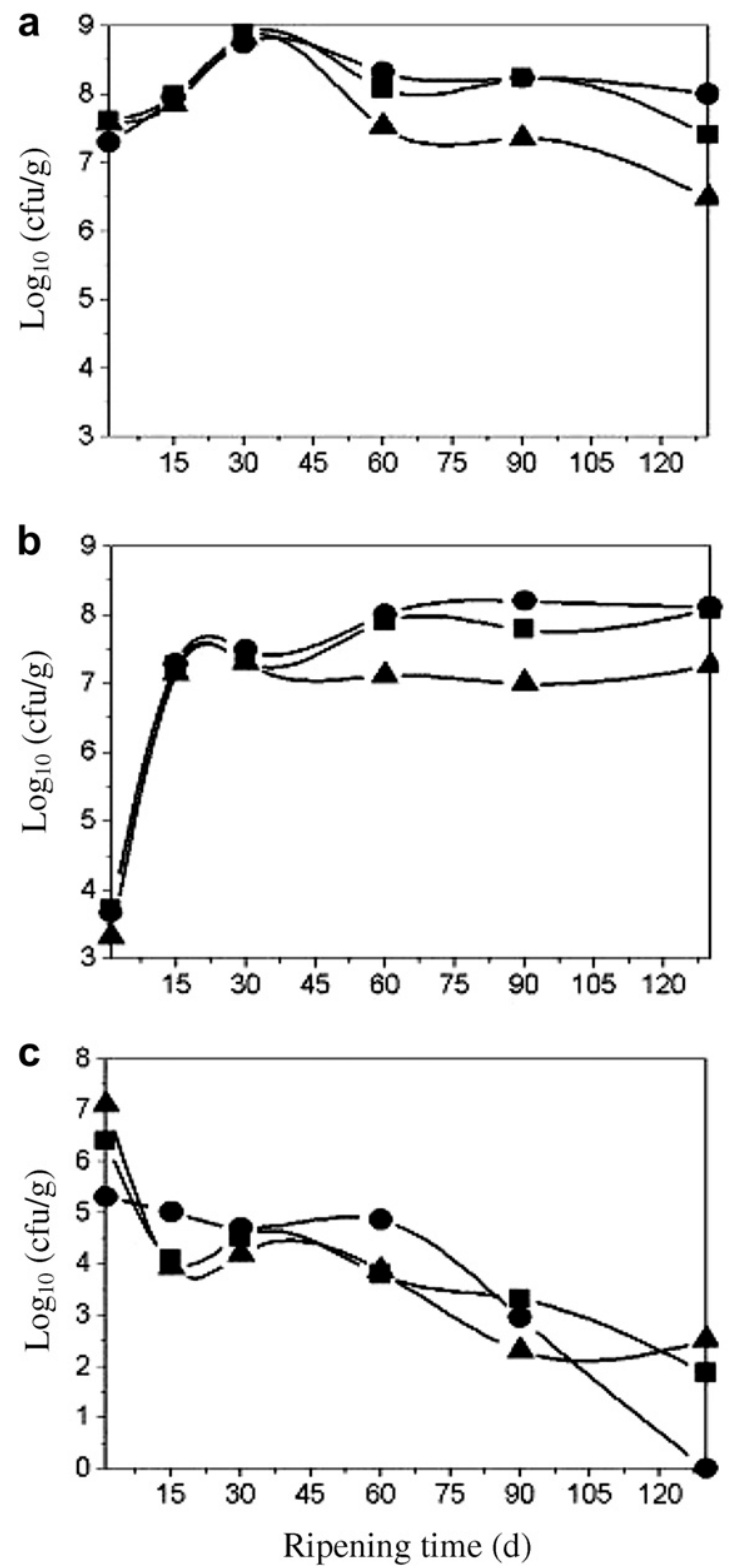

\section{Results and discussion}

Microbiological analyses

Milk

The average total viable counts of raw milk, from dairies A, B and $\mathrm{C}$, were $2.7 \times 10^{7}, 2.5 \times 10^{7}$, and $3.2 \times 10^{7} \mathrm{cfu} \mathrm{ml}^{-1}$, respectively. The most representative groups therein were (sorted by decreasing magnitude): lactococci, Enterobacteriaceae and micrococci. These figures indicate that raw milk is apparently of poor quality. Corresponding $\mathrm{pH}$ values were 6.53, 6.76 and 6.74, respectively.

\section{Cheese}

The evolution, throughout ripening, of viable cell counts of the various microbial groups in cheeses, from dairies A, B and C, is shown in Fig. 1. In all cases, the average total viable counts (Fig. 1a) reached their maximum value $\left(\mathrm{ca} .6 .3 \times 10^{8} \mathrm{cfu} \mathrm{g}^{-1}\right)$ by 30 days of ripening, and subsequently dropped to an average of
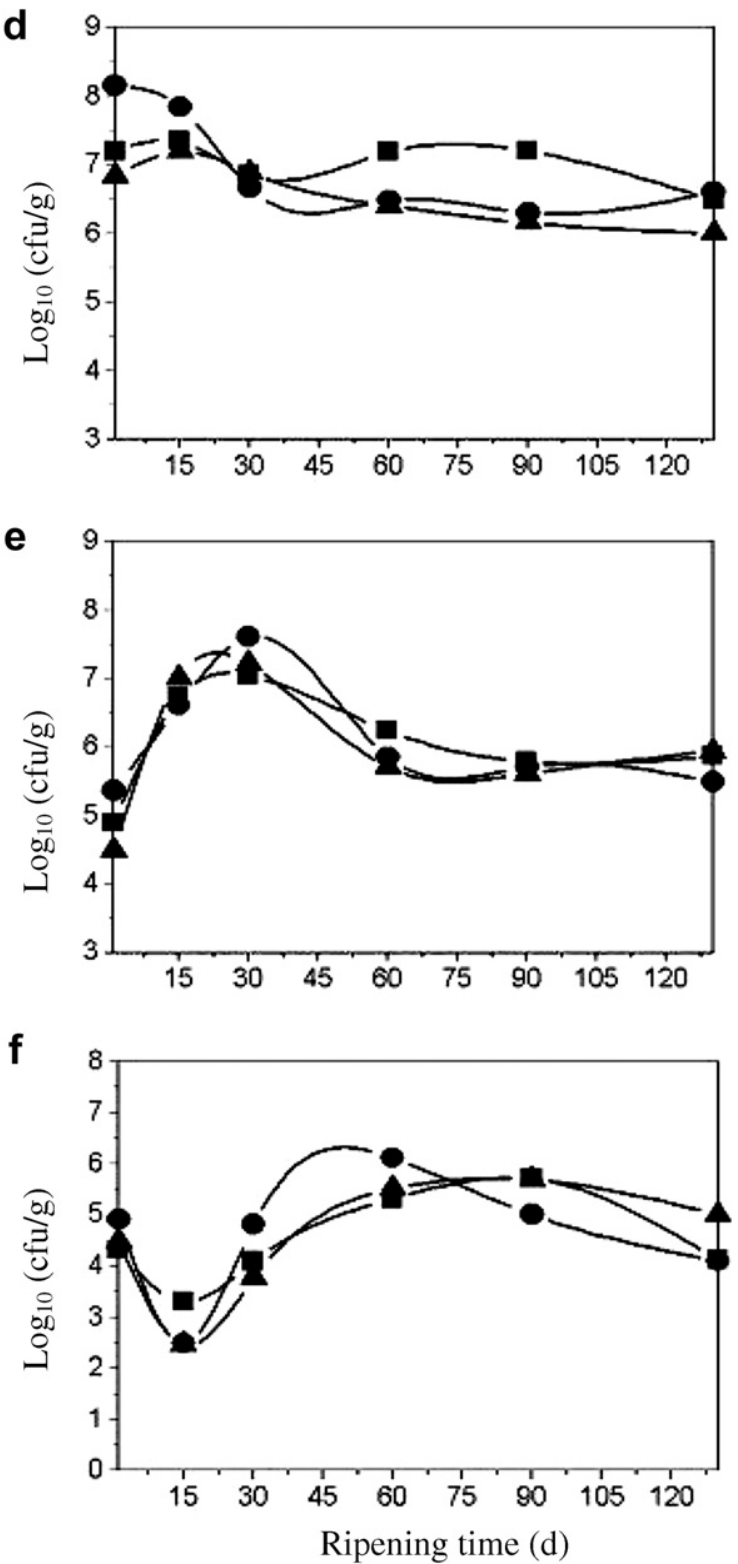

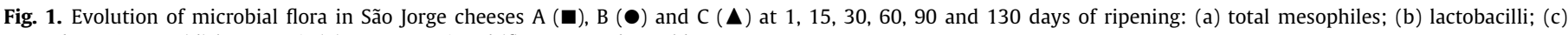
Enterobacteriaceae; (d) lactococci; (e) enterococci and (f) yeasts and moulds. 
$3.1 \times 10^{7} \mathrm{cfu} \mathrm{g}^{-1}$ towards the end of ripening. Presumptive lactobacilli (Fig. 1b) underwent an increase of four log cycles within the first 30 days, eventually levelling off at $10^{7}-10^{8} \mathrm{cfu}^{-1}$ at later stages of ripening; they consequently represented the dominant microbial group, followed closely by lactococci and enterococci. Comparable microbiological results were found for related cheeses (Gobbetti et al., 2002; Licitra et al., 2000). Peveda, Sousa, Cabezas, and McSweeney (2003) also found an increase in presumptive lactobacilli by the end of the ripening period, in the case of Manchego cheese. NSLAB, predominantly mesophilic lactobacilli, usually dominate the microflora of Cheddar-type cheese during much of its ripening, thus contributing to final cheese aroma. In fact, NSLAB possess a wide range of proteolytic enzymes (di Cagno, Quinto, Corsetti, Minervini, \& Gobbetti, 2006) and may contribute toward the formation of short peptides and free amino acids (Bouton, Guyot, \& Grappin, 1998; Singh et al., 2003).

The poor quality of raw milk employed in cheese making is also reflected in the characteristics of 130 day old ripened cheeses from dairies A and C, which still presented detectable numbers of Enterobacteriaceae (Fig. 1c); conversely, that microbial group showed the highest decrease in viable cell numbers and was not even detected in cheeses from dairy B, by 130 days of ripening. Viable cell counts on M17 agar (i.e. presumptive lactococci) also underwent a general decrease over the ripening period (Fig. 1d); unpublished results in our $R \& D$ group showed that the colonies growing in that medium are mostly of enterococci. Viable cell counts on KAA medium, which is supposedly (more) specific for enterococci, reached a maximum, i.e. $3.2 \times 10^{7} \mathrm{cfu}^{-1}$, by 30 days of ripening; by the end of ripening, their viable numbers decreased to $(1.0-3.2) \times$ $10^{5} \mathrm{cfu} \mathrm{g}^{-1}$ (Fig. 1e).

Yeasts and moulds grown on OGYEA medium reached a maximum within the range $10^{5}-10^{6} \mathrm{cfu} \mathrm{g}^{-1}$, by 90 days of ripening (Fig. 1f).

\section{Chemical analysis}

The average $\mathrm{pH}$, as well moisture, salt, fat and protein contents of cheeses, from the three dairies, by 1, 30, 90 and 130 days of ripening, are shown in Table 1. By the end of the ripening time, the compositions of the distinct cheeses were essentially similar, irrespective of dairy of origin. However, one day old cheeses, from different dairies, showed more variability in their moisture content than did cheeses by 130 days of ripening; this may reflect differences in manufacturing methods between dairies. The final moisture content ranged from 38 to $42 \%$ and, as expected, it decreased as ripening time elapsed.

The $\mathrm{pH}$ of cheeses lay between 5.4 and 5.7, upon manufacture; subsequently, it reached a minimum of 5.1 by 30 days of ripening, and exhibited a slight increase thereafter - probably as a result of secondary proteolytic activity by bacteria and yeasts, and consequent build up of free amino acids and even ammonia (Kosikowski, 1997).

Low salt levels were recorded in curds; since São Jorge is handsalted, this probably indicates non-homogeneous salt distribution soon after cheese making - a condition that may constrain the rate of proteolysis in the said cheeses during later ripening (Thomas \& Pearce, 1981). At late maturation stages, salt concentration increased to ca. $5 \%(\mathrm{w} / \mathrm{w})$ in all cheeses - so transport by diffusion eventually levels off the initial concentration gradient of that solute. Because salt concentration considerably affects bacterial growth, the dominant groups found at late stages are those able to grow at relatively high salt concentrations (Thomas \& Pearce, 1981); these include non-starter bacteria, as well as moulds, which possess a potent proteolytic system (Pavia, Trujillo, Guamis, \& Ferragut, 2000).

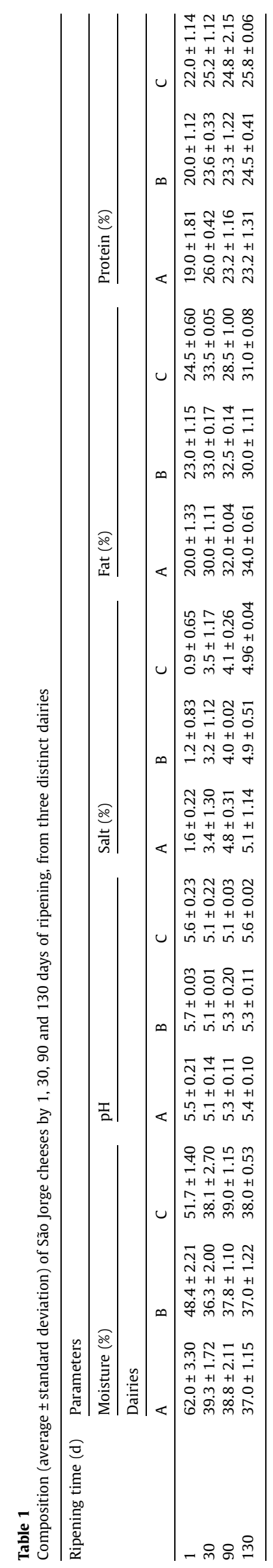




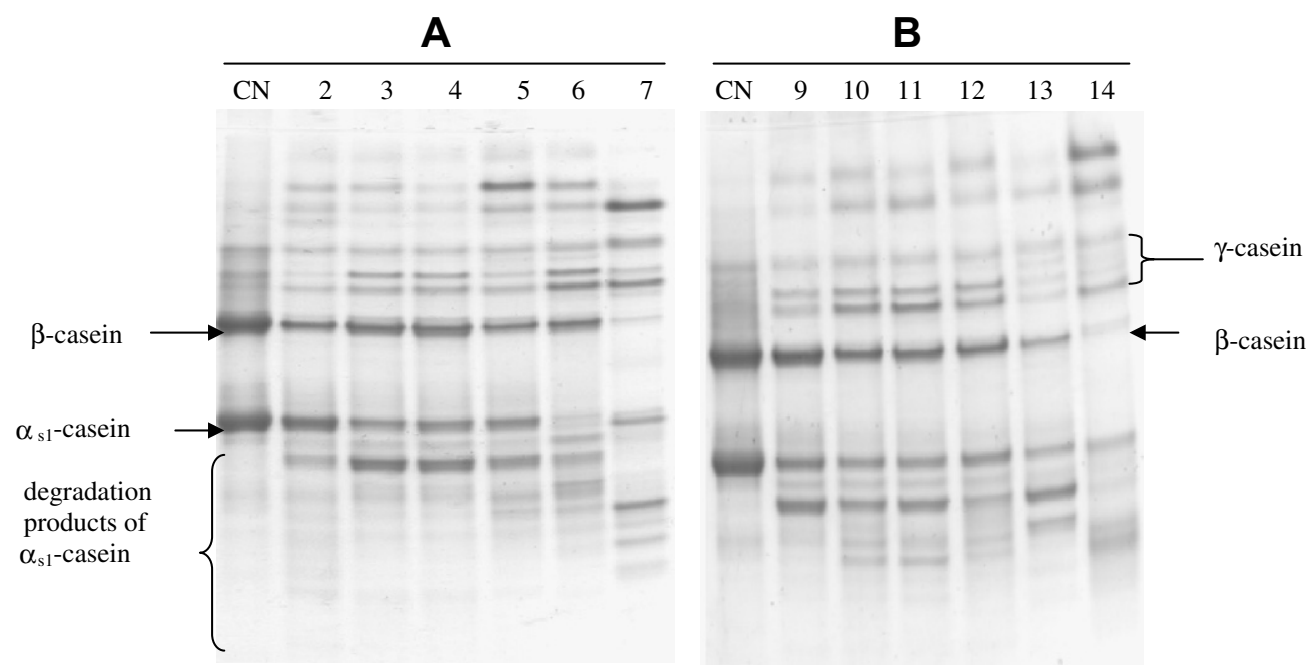

Fig. 2. Urea-polyacrylamide gel electrophoresis of São Jorge cheeses A and B after 1, 15, 30, 60, 90 or 130 days of ripening. Lanes 1, 8 and 15 Na- caseinate; lanes 2-6 cheese A; lanes $9-14$ cheese $\mathrm{B}$.
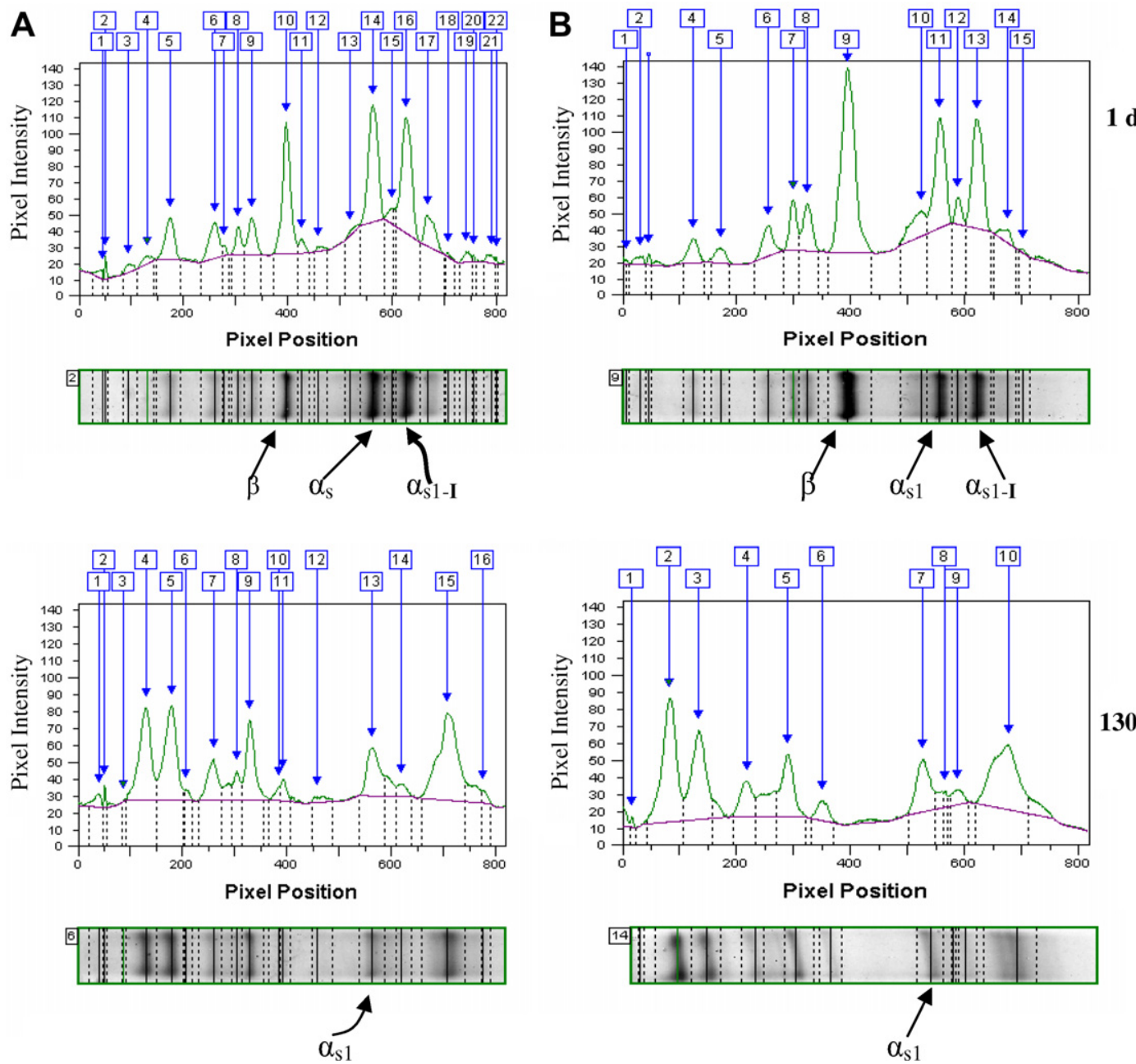

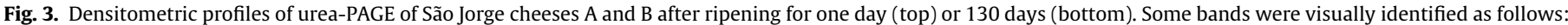

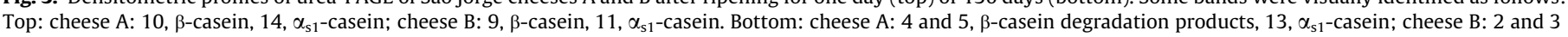
$\beta$-casein, 11 , degradation products, $8, \alpha_{s 1}$-casein.

The total protein content changed from ca. $19 \%$ at manufacture, up to ca. $26 \%(\mathrm{w} / \mathrm{w})$ by the end of ripening. Such a variation can be attributed to the concomitant decrease in moisture content that decreases the overall weight basis. 
The fat-in-moisture content increased, in a gradual fashion, throughout ripening - up to $30 \%(\mathrm{w} / \mathrm{w})$ in cheeses from dairy $\mathrm{B}$, and $34 \%(\mathrm{w} / \mathrm{w})$ in cheeses from dairy A.

Because cheeses become more similar in their composition as the ripening progresses, the ripening conditions have a key role, tending toward more consistent final cheeses. Thus, having a common place (i.e at the same controlled environmental conditions) to ripen all São Jorge cheeses, will eliminate (or at least lower) the common constrains of flavour variability among cheeses from different dairies.

\section{Proteolysis analyses}

\section{General}

Acceptable cheese flavour requires a well-balanced breakdown of caseins, brought about by chymosin and plasmin, to large peptides, and of those into small peptides and amino acids, brought about by proteinases and peptidases released by starter and nonstarter bacteria during ripening (Singh et al., 2003). While electrophoresis methods (e.g. urea-PAGE) are widely used to characterize primary proteolysis in cheese (Park, 2001; Pavia et al., 2000), the subsequent secondary proteolysis can be studied via chromatographic methods (e.g. RP-HPLC).

\section{Electrophoresis anddensitometric analysis}

Electrophoretograms of cheese samples by 1, 15, 30, 60, 90 and 130 days of ripening, are shown, respectively, in lanes 2 to 7 (for dairy A) and lanes 9-14 (for dairy B) of Fig. 2. Bands in electrophoretograms and corresponding peaks, generated following densitometric analysis (Fig. 3), indicated that degradation of $\beta$ - and $\alpha_{\mathrm{s} 1}$-casein occurs as early as by day one (Fig. 2, lanes 2-9). This initial breakdown is commonly ascribed to the proteolytic activity of rennet and plasmin - both of which are present in the curd as residual enzymes (Peveda et al., 2003; Singh et al., 2003; Sousa et al., 2001). As ripening time continued lower intensities of the bands corresponding to $\beta$ - and $\alpha_{s 1}$-caseins were observed - which is an expected result, in view of the ongoing proteolysis. The rates of hydrolysis of $\alpha_{s 1}$-casein were slightly greater than those of $\beta$ casein, in both cheeses. The band corresponding to the former becomes fainter faster than bands of the latter, as the ripening progresses (Fig. 2). These results are in agreement with those reported by Marcos et al., 1979 .

Such putative degradation correlates with formation, and increase of $\alpha_{\mathrm{s} 1^{-}}$and $\beta$-casein (i.e. $\gamma$-caseins) degradation products, whose relative concentrations are observed in the densitometric analysis depicted in Fig. 3: by 130 days of ripening the bands corresponding to $\beta$ - or $\alpha_{\mathrm{s} 1}$-casein are almost absent, and bands corresponding to an increase of their degradation products is apparent, indicative of extensive proteolysis of both caseins in cheese; in fact, the densitometric analysis shows that, by day one, peaks 10 and 14 pertaining to cheese from dairy $A$, and peaks 9 and 11 pertaining to cheese from dairy $B$, are accounted for by $\beta$-casein and $\alpha_{s 1}$-casein, respectively; by 130 days, the peak corresponding to $\beta$-casein vanishes, and concomitantly new peaks (e.g. peaks four and five in the case of cheese from dairy $A$, and peaks two and three in the case of cheese from dairy B) a rise, and this can be related to formation of $\gamma$-caseins. This trend (i.e increase in concentration of breakdown products of casein fractions, with a concomitant lowering of $\alpha_{\mathrm{s} 1}$-and $\beta$-casein, as the aging time advanced) has also been reported by Park (2001), for a variety of cheeses, via use of densitometric analysis.

Primary proteolysis in most cheese varieties is mainly due to the action of residual rennet and plasmin in the curd - as emphasized before; however, high cooking temperature, high $\mathrm{pH}$ and low
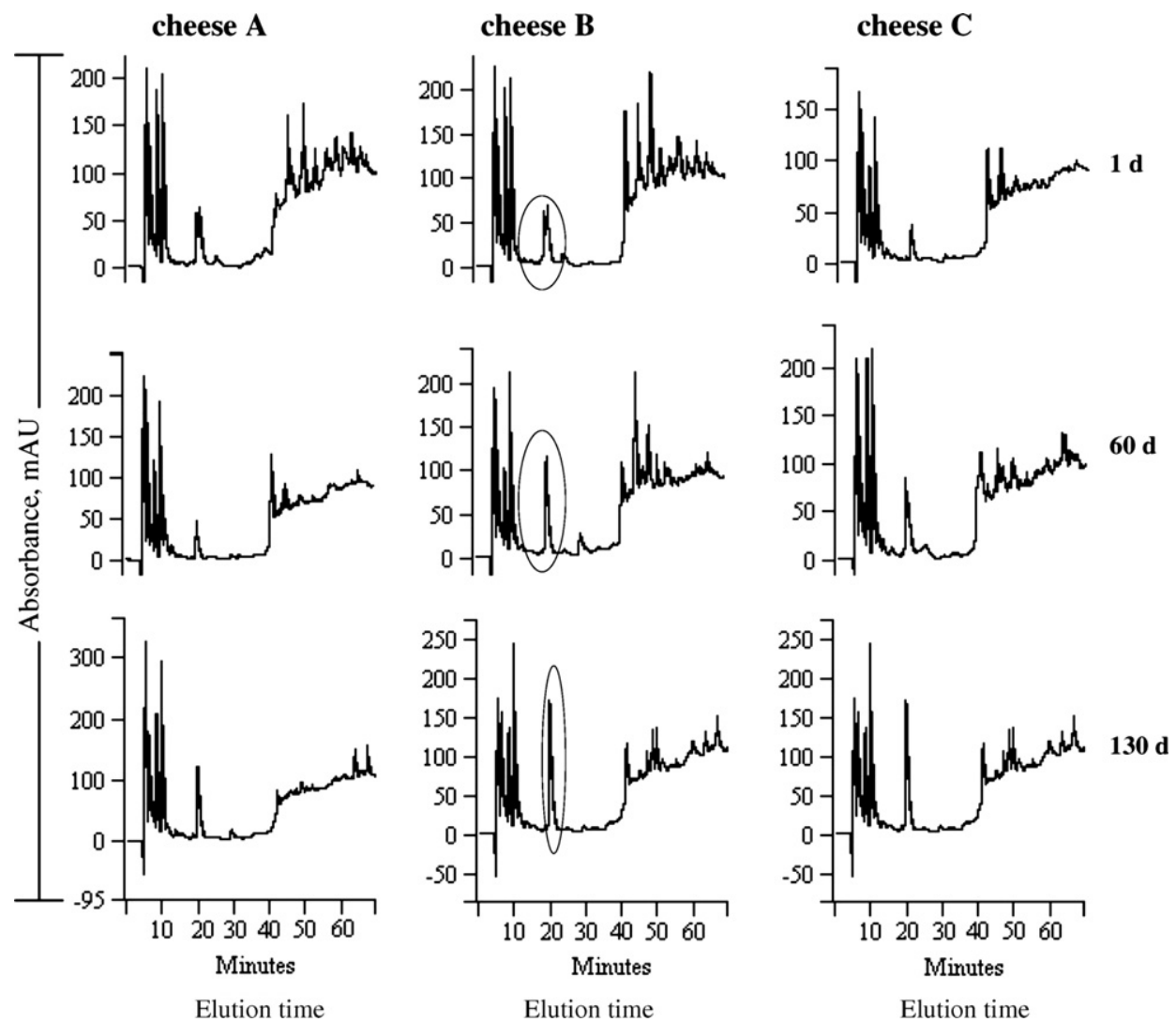

Fig. 4. RP-HPLC chromatograms of the $\mathrm{pH}$ 4.6-soluble fractions at 1, 60 and 130 days of ripening.

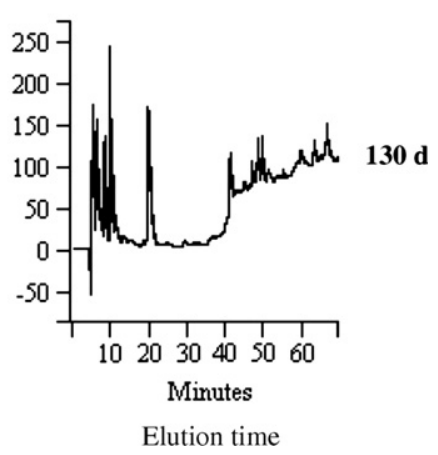



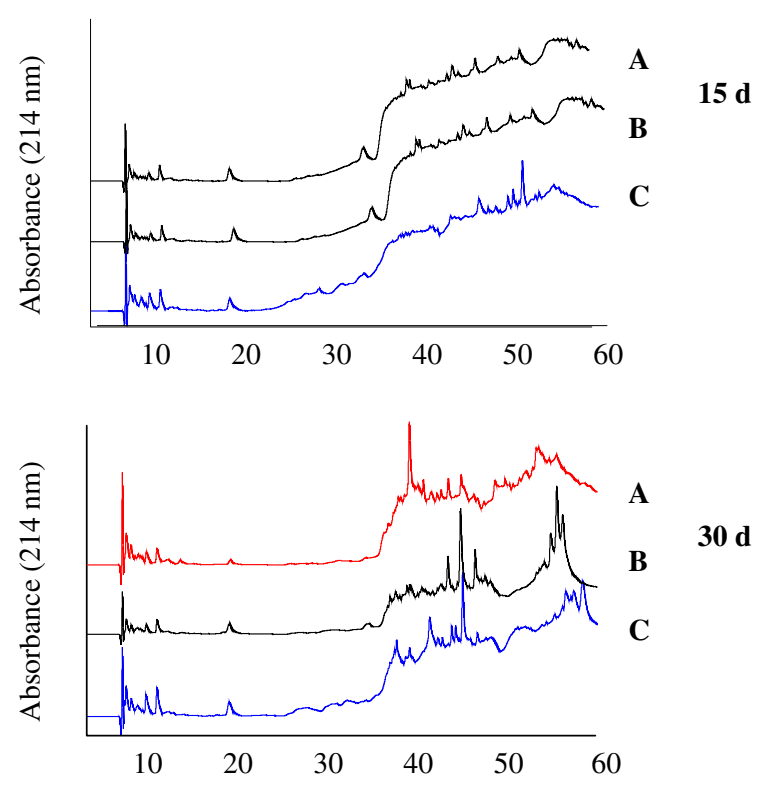

$30 \mathrm{~d}$

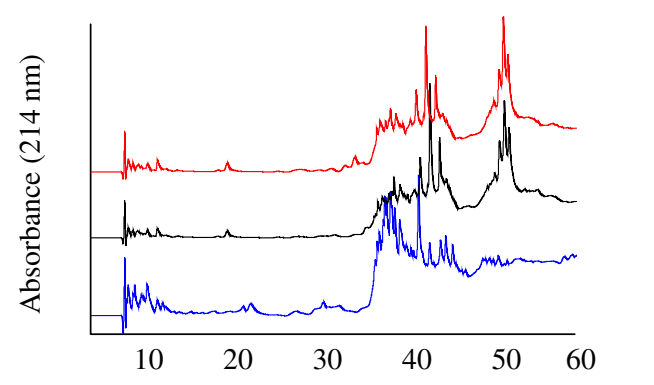

A

B

C $60 \mathrm{~d}$

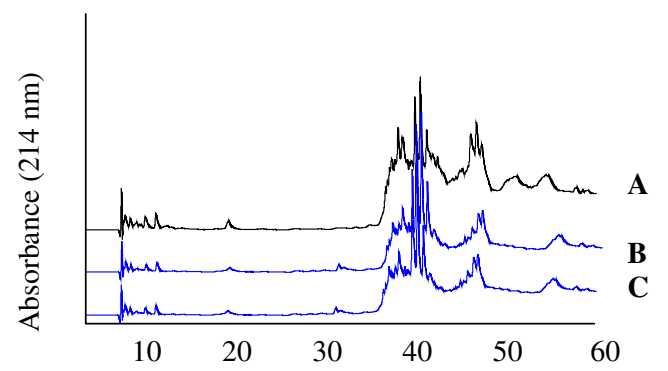

$90 \mathrm{~d}$

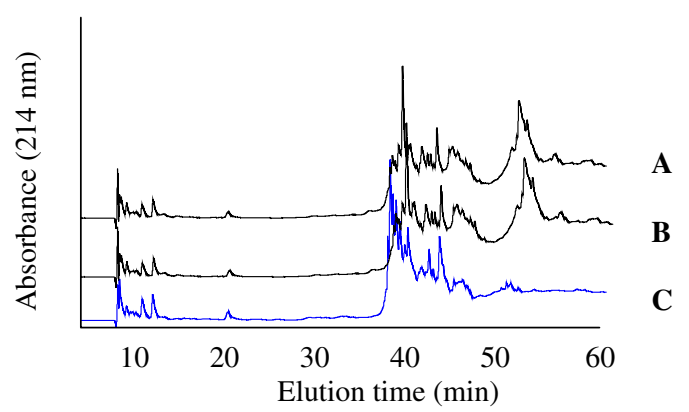

Fig. 5. RP-HPLC chromatograms of the ethanol $\left(70 \mathrm{ml}, 100 \mathrm{ml}^{-1}\right)$-insoluble fractions at $15,30,60,90$ and 130 days of ripening.

moisture level contribute to a decrease in activity of rennet in cheese (Sousa et al., 2001), but to an increase in activity of plasmin on $\beta$-casein (Singh et al., 2003). Manufacture of São Jorge cheese involves cooking the curd at $35-37^{\circ} \mathrm{C}$ - which leads to a cheese that is ca. $39 \%(\mathrm{w} / \mathrm{w})$ moisture and bears a $\mathrm{pH}$ in the range $5.4-5.7$, by the end of ripening (4-6 months). Therefore, most residual rennet in São Jorge cheese may remain active throughout the ripening period, and our results indicate, indeed, that both $\beta$ - and $\alpha_{\mathrm{s} 1}$-caseins are extensively degraded within 130 days, following manufacture of São Jorge cheese.

São Jorge cheese is commonly manufactured in large sizes, typically $15 \mathrm{~cm}$ in height, $35 \mathrm{~cm}$ in diameter and $15 \mathrm{~kg}$ in weight. This geometrical shape and size could result in variable rates of proteolysis, from the outer surface to the inner bulk of cheese (Licitra et al., 2000; Melilli et al., 2004). Although a serious effort was made to obtain representative samples of the whole cheese, inducing a weighted average of depths, two of the samples analysed by urea-PAGE might have failed to justify such an assumption. This might explain the (somewhat unexpected) appearance of a $\alpha_{\mathrm{s} 1}$-casein band in cheese A, and of a $\beta$-casein band (f108-209) in cheese $B$, both by 130 days.

\section{Liquid chromatography}

Water-soluble fractions : The profiles of water-soluble $(\mathrm{pH}$ 4.6) fractions of cheeses, by 1, 60 and 130 days of ripening, as obtained by RP-HPLC, are shown in Fig. 4. Visual inspection reveals minor differences between the aforementioned profiles, at all ripening stages. The most relevant difference is associated with the peak characterized by a retention time of $20 \mathrm{~min}$ (which was duly outlined); this peak increased in size with ripening time, which indicates an increase in concentration of the corresponding peptide.

Ethanol-soluble fractions : The profiles of ethanol-soluble fractions of cheeses by 15, 30, 60, 90 and 130 days, as obtained by RP-HPLC, are shown in Fig. 5. Two distinct regions are apparent: one with retention times ranging over 0-30 min - hydrophilic region (Hayaloglu et al., 2004) and another with retention times ranging over 35-60 min - hydrophobic region. In the former, several peaks (especially the one eluting at $20 \mathrm{~min}$ ) were present in the chromatograms of all São Jorge cheeses, hence providing evidence for the presence of free amino acids and small peptides, although at relatively low concentrations (Hayaloglu et al., 2004). In the case of retention times above $35 \mathrm{~min}$, larger and distinct peaks appear by $15,30,60$ and 130 days; these represent hydrophobic peptides (Pavia et al., 2000), some of which may cause bitterness.

The amount and composition of the amino acid mixture in cheese has long been used as an index of cheese ripening (Fox, McSweeney, \& Singh, 1995). In at least some instances, these parameters correlate with flavour and body development. A full description of cheese proteolysis requires identification of the peptide bonds cleaved, which requires isolation of proteolytic products and determination of their structures. This will be addressed in future work.

\section{Conclusion}

The predominant microbial genus harboured in São Jorge cheese, by the end of ripening, is Lactobacillus. Presumptive lactococci, enterococci and yeasts, by that time, were found at levels high enough to potentially influence the final characteristics of that cheese. Urea-PAGE indicates that there is an extensive primary proteolysis of $\alpha_{s 1}$ - and $\beta$-casein in fully ripened São Jorge cheese. In addition, RP-HPLC indicates that ripened cheeses possess a high concentration of peptides - especially those eluting in the hydrophobic region. These findings may constitute useful tools for characterization, and eventual quality improvement of São Jorge cheese, and may allow comparison of proteolytic patterns in genuine PDO São Jorge cheese with those of imitation cheeses illegally designated and marketed as São Jorge. 


\section{Acknowledgements}

Partial funding for this work was received via a Ph.D. fellowship (Ref. BD), granted by POCTI and FCT (Portugal), with financial comparticipation by FEDER (EU).

The authors would like to thank Nina Raposo - for general laboratory technical support, and Ciara Brickley for advice and expertise pertaining to HPLC work.

\section{References}

Blakesley, R. W., \& Boezi, J. A. (1997). A new staining technique for proteins in polyacrylamide gels using coomassie brilliant blue G250. Analytical Biochemistry, 82, 580-581.

Bouton, Y., Guyot, P., \& Grappin, R. (1998). Preliminary characterization of microflora of Comté cheese. Journal of Applied Microbiology, 85, 123-131.

de Llano, D. G., Polo, M. C., \& Ramos, M. (1995). Study of proteolysis in artisanal cheese-high performance liquid chromatography of peptides. Journal of Dairy Science, 78, 1018-1024.

di Cagno, R., Quinto, M., Corsetti, A., Minervini, F., \& Gobbetti, M. (2006). Assessing the proteolytic and lipolytic activities of single strains of mesophilic lactobacilli as adjunct cultures using a Caciotta cheese model system. International Dairy Journal, 16, 119-130.

Farkye, N., \& Fox, P. F. (1991). Preliminary study on the contribution of plasmin to proteolysis in Cheddar cheese: cheese containing plasmin inhibitor, 6aminohexanoic acid. Journal of Agriculture and Food Chemistry, 39, 786-788.

Fox, P. F. (1993). Cheese: An overview. In P. F. Fox (Ed.). Cheese: Chemistry, Physics, and Microbiology (Vol. 1, pp. 1-36). London: Chapman \& Hall.

Fox, P. F., \& McSweeney, P. L. H. (1996). Proteolysis during ripening. Food Reviews International, 12, 457-509.

Fox, P. F., McSweeney, P. L. H., \& Singh, T. K. (1995). Methods for assessing proteolysis in cheese during ripening. In E. L. Malin \& M. H. Tunick (Eds.) Chemistry of structure/function relationships in cheese. Adv. Exptl. Med. Biol. (Vol. 367, pp. 161-194). New York, NY: Plenum Press.

Gaiaschi, A., Beretta, B., Poiesi, C., \& Conti, A. (2001). Proteolysis of $\beta$-casein as marker of Grana-Padano cheese ripening. Journal of Dairy Science, 84, 60-65.

Gobbetti, M., Morea, M., Baruzzi, F., Corbo, M. R., Matarante, A., Considine, T., et al. (2002). Microbiological, compositional, biochemical and textural characteristics of Caciocavallo-Pugliese cheese during ripening. International Dairy Journal, 12, 511-523.

Grappin, R., Beauvier, E., Bouton, Y., \& Pochet, S. (1999). Advances in the biochemistry and microbiology of Swiss-type cheeses. Le Lait, 79, 3-22.

Hayaloglu, A. A., Guven, M., Fox, P. F., Hannon, J. A., \& McSweeney, P. L. H. (2004). Proteolysis in Turkish white-brined cheese made with defined strains of Lactococcus. International Dairy Journal, 14, 599-610.
International Dairy Federation (1982). Determination of total solids content (cheese and processed cheese). IDF Standard 4A: 1982. Brussels, Belgium. Internationa Dairy Federation.

International Dairy Federation (1993). Determination of nitrogen content (Kjeldah method) and calculation of crude protein content. IDF Standard 20A. Brussels, Belgium. International Dairy Federation.

James, C. S. (1999). Analytical chemistry of foods. Oxford, UK.: Chapman \& Hall.

Kongo, J. M., Ho, A. J., Malcata, F. X., \& Wiedmann, M. (2006). Detection and characterization of Listeria monocytogenes in São Jorge (Portugal) cheese production. Journal of Dairy Science, 89, 4456-4461.

Kosikowski, F. V. (1997). Cheeses and Fermented Milk Foods. (pp. 437-440). MI. USA Edwards Bros., Ann Arbor.

Kuchroo, C. N., \& Fox, P. F. (1982). Soluble nitrogen in Cheddar cheese: comparison of extraction procedures. Milchwissenschaft, 37, 331-335.

Licitra, G., Campo, P., Manenti, M., Porteli, G., Scuderi, S., Carpino, S., et al. (2000). Composition of Ragusano Cheese during aging. Journal of Dairy Science, 83, 404-411.

Marcos, A., Esteban, M. A., León, F., \& Fernandez-Salguero, J. (1979). Electrophoretic patterns of European cheese: comparison and qualification. Journal of Dairy Science, 62, 892-900.

Melilli, C., Barbano, D. M., Manenti, M., Lynch, J. M., Carpino, S., \& Licitra, G. (2004) Lipolysis and proteolysis in Ragusano cheese during brine salting at different temperatures. Journal of Dairy Science, 87, 2359-2374.

Park, Y. W. (2001). Proteolysis and lipolysis of goat milk cheese. Journal of Dairy Science, 84, 84-92.

Pavia, M., Trujillo, A. J., Guamis, B., \& Ferragut, V. (2000). Proteolysis in Manchegotype cheese salted by brine vacuum impregnation. Journal of Dairy Science, 83, 1441-1447.

Peveda, J. M., Sousa, M. J., Cabezas, L., \& McSweeney, P. L. H. (2003). Preliminary observations on proteolysis in Manchego cheese made with a defined-strain starter culture and adjunct starter (Lactobacillus plantarum) or commercial starter. International Dairy Journal, 13, 169-178.

Rehman, S. U., Feeney, E. P., McSweeney, P. L. H., \& Fox, P. F. (1998). Inhibition of residual coagulant in cheese using pepstatin. International Dairy Journal, 12, 987-992.

Rehman, S. U., McSweeney, P. L. H., Banks, J. M., Brechany, E. Y., Muir, D. D., \& Fox, P. F. (2000). Ripening of Cheddar cheese made from blends of raw and pasteurized milk. International Dairy Journal, 10, 33-44.

Shalabi, S. I., \& Fox, P. F. (1987). Electrophoretic analysis of cheese: comparison of methods. Irish Journal of Food Science and Technology, 11, 135-151.

Singh, T. K., Drake, M. A., \& Caldwallader, K. R. (2003). Flavor of Cheddar cheese: a chemical and sensory perspective. Comprehensive Reviews in Food Science and Food Safety, 2, 139-162.

Sousa, M. J., Ardo, Y., \& McSweeney, P. L. H. (2001). Advances in the study of proteolysis during cheese ripening. International Dairy Journal, 11, 327-345.

Thomas, T. D., \& Pearce, K. N. (1981). Influence of salt on lactose fermentation and proteolysis in Cheddar cheese. New Zealand Journal of Dairy Science and Technology, 16, 253-259. 